\title{
The Presence of C. P. Cavafy in Greek Education: Landmarks and Gaps
}

\author{
La presencia de C.P. Cavafis en la educación griega: paisajes y \\ huecos.
}

\author{
La presència de C.P. Kavafis en l'educació grega: paisatges i forats \\ Sotiria Kalasaridou. Aristotle University of Thessaloniki, Greece. \\ roula.kalas@gmail.com \\ https://orcid.org/0000-0002-7456-703X
}

\begin{abstract}
This article aims to highlight the crucial stages of C.P. Cavafy's presence in education through textbooks about literature from 1930 until today. More specifically, the research is constructed around two areas: a) the fundamental role of literary criticism and how it was related to the introduction of C.P. Cavafy in education in 1930, b) the degree of osmosis between History of Greek Literature and Education. The methodological criteria of the research are drawn from different areas, such as: i) literary criticism, ii) history of education and educational policy, iii) history of textbook anthologies, and iv) poetry anthologies. During a course of eighty years, C. P. Cavafy is found in thirtyfive textbooks, teachers' textbooks and curricula; 'Ithaka' is the most anthologized poem - twelve times. The positive opinions by the critics and the momentum of school anthologies that tried a holistic approach to poetry defined the inclusion of C. P. Cavafy in the school anthologies during the educational reform of 1929-1932. The evaluation of Cavafy in the History of Modern Greek Literature by C. Th. Dimaras surpasses the efforts made by the critics of that time. Moreover, Linos Politis also holds a part of the restoration of C. P. Cavafy as far as the school textbooks are concerned, as his History of Modern Greek Literature, as well as his poetic anthology, determined the school literary canon from the days of the Restoration of Democracy (1974) ${ }^{1}$ until now.
\end{abstract}

Key Words: History of Education in Greece; Cavafian Poetry; Literary Criticism; Educational Policy; Literature and Education

\section{Resumen}

Este artículo trata de resaltar las etapas cruciales de la presencia de C.P. Cavafis en la educación a través de libros de texto sobre literatura desde 1930 hasta la actualidad. Más específicamente, la investigación está construida sobre dos áreas: a) el papel fundamental de la crítica literaria y como está relacionada con la introducción de C.P. Cavafis en la educación en 1930, b) el grado de ósmosis entre la historia de la literatura griega y la educación. Los criterios metodológicos de la investigación se delinean a través de diferentes áreas como: a) la crítica literaria, b) la historia de la educación y la política educativa, c) la historia de las antologías escolares y d) las antologías poéticas. En el curso de

${ }^{1}$ Greece was under military dictatorship, which was imposed on the $21^{\text {st }}$ of April 1967 , also known as the Regime of the Colonels or the Junta. The dictatorship lasted for seven years, ending on the $24^{\text {th }}$ of July 1974. 
ocho años, C.P. Cavafis se encuentra en 35 libros de texto, manuales de profesores y currículos. "Itaca" es el poema que aparece en más antologías (12 veces). Las opiniones positivas de los críticos y el impulso de las antologías escolares que buscaron un enfoque holístico de la poesía, definieron la inclusión de C.P. Cavafis en las antologías escolares durante la reforma educativa de 1929-1932. La evaluación de Cavafis en la Historia de la Literatura Moderna Griega (en griego) de C.Th. Dimaras sobrepasa los esfuerzos hechos por los críticos en aquel periodo. Además, Linos Politis también contribuyó en parte a la restauración de C.P. Cavafis respecto de los libros de texto en tanto que su Historia de la Literatura Griega Moderna, así como su antología poética, determinaros el canon literario escolar desde los días de la restauración de la democracia (1974) hasta ahora.

Palabras clave: historia de la educación en Grecia; poesía de Cavafis; política educacional; literatura y educación

Resum

Aquest article tracta de ressaltar les etapes crucials de la presència de C.P. Kavafis en l'educació a través de llibres de text sobre literatura des de 1930 fins l'actualitat. Més específicament, la investigació està construïda sobre dues àrees: a) el paper fonamental de la crítica literària i com està relacionada amb la introducció de C.P. Kavafis en l'educació el 1930, b) el grau d'osmosi entre la història de la literatura grega i l'educació. Els criteris metodològics de la investigació es dibuixen a través de diferents àrees com: a) la crítica literària, b) la història de l'educació i la política educativa, c) la història de les antologies escolars i d) les antologies poètiques. En el transcurs de huit anys, C.P. Kavafis es troba en 35 llibres de text, manuals de professors i currículums. "Itaca" és el poema que apareix en més antologies (12 vegades). Les opinions dels crítics i l'impuls de les antologies que buscaren un enfocament holístic de la poesia, van definir la inclusió de C.P. Kavafis en les antologies escolars durant la reforma educativa de 1923-1932. L'avaluació de C.P. Kavafis a la Història de la literatura grega moderna (en grec), de C.Th. Dimaras sobrepassa els esforços fets pels crítics en aquell període. A més a més, Linos Politis també va contribuir en part a la restauració de C.P. Kavafis respecte dels llibres de text en tant que la seua la Història de la literatura grega moderna (en grec), a més de la seua antologia poètica, van determinar el cànon literari escolar des dels dies de la restauració de la democràcia (1974) fins ara.

Paraules clau: història de l'educació a Grècia; poesia de Kavafis; política educacional; literatura i educació

\section{Introduction}

Critics and the historians of literature are now certain as to what extent C. P. Cavafy led poetry to modernism in terms of form as well as meaning. The modernism in Greek literature is primarily seen through the work of the Alexandrian poet, whose ground-breaking transformation of the poetic rhythm, implied strain, his association of the past with the present in diachronic terms as well as his dramatic style and irony caused amazement (Vagenas, 1984; Vagenas, 2003; Kokoris, 2006). This article tracks the path of C. P. Cavafy's poetry in education since the school literary canon first absorbed C. P. Cavafy until the present day in an attempt to clarify the relationship between education and the history of literature as well as in the field of 
literary criticism, at a time when history of literature did not yet have a specific pattern of how

This article attempts to trace

C. P. Cavafy's poetic journey in education from 1930 until today and to clarify the interactions between education, history of literature and critique regarding C. P. Cavafy within the last eighty years. C. P. Cavafy's journey into the school literary canon is full of gaps and reappearances, but enough to allow us to shed light upon the poet's presence and in some cases his provocative absence from education and to discover ruptures within this journey.

to evaluate his poetic work. The ill-defined relation between literary critique and the first incorporation of $\mathrm{C}$.

P. Cavafy in the curriculum, as well as the inability of related articles in literature journals to evaluate and fully redefine the aesthetic and ideological notions of the involved anthologists during the last decade set a number of questions: (a) was the critique the fundamental factor for which Cavafy was included in education? (b) How did the history of literature act as a filter in terms of including Cavafy in education? (c) Was the role of the history of literature of the same importance throughout the whole journey of Cavafy's works in school?

This article attempts to trace C. P. Cavafy's poetic journey in education from 1930 until today and to clarify the interactions between education, history of literature and critique regarding C. P. Cavafy within the last eighty years. C. P. Cavafy's journey into the school literary canon is full of gaps and reappearances, but enough to allow us to shed light upon the poet's presence and in some cases his provocative absence from education and to discover ruptures within this journey. It is these ruptures, indeed, that are the indicators of the rediscovery of Cavafy in the textbooks. The criteria of editing Cavafy's journey in education derive from a variety of different fields: (a) literary criticism; (b) the History of Modern Greek Literature; (c) poetic anthologies; (d) the history of school literary anthologies (textbooks); and (e) educational policy.

\section{The time of polyphony in textbooks anthologies (1930-1938)}

C. P. Cavafy makes his first appearance in the school literary canon in 1930 with 'Trojans' 2 and 'Thermopylae' in Modern Greek Readings (Neohellinika Anagnosmata), edited for grade 5 of secondary education as well as with 'Candles' and 'Waiting for the Barbarians' found in Modern

\footnotetext{
${ }^{2}$ Regarding the poems' titles, the following three English publications have been used: a) C. P. Cavafy, Collected Poems, translated by Edmund Keely and Philip Sherrard (edited by George Savidis), Princeton University Press, Princeton New Jersey, 1975, b) The Complete Poems of C.P. Cavafy translated by Rae Dalven (with an introduction by W.H Auden), Harcourt Brace \& Company, New York and London, A Harvest / HBJ Book, 1976 and c) C.P. Cavafy, The Collected Poems, translated by Evangelos Sachperoglou, Greek text edited by Anthony Hirst, with an introduction by Peter Mackridge, Oxford - New York, Oxford University Press, 2007.
} 
Greek Readings (Neohellininka Anagnosmata) for grade 6 of secondary education also in 1930. One year later, in 1931, Cavafy is introduced in grade 1 of secondary education with the rimmed poem 'Supplication', whereas in that same year Cavafy is also introduced in Professional Education with the same poem as part of the curriculum for the second grade of Middle and Technical School of Trade (Varelas, 2007; Paroritis and Argyropoulos, 1930; Tambakopoulou, 1930).

The aforementioned school textbooks that were edited during the time of 'polyphony', namely the time of the use of more than one textbook for the teaching of literature, were influenced by demoticism (the use of demotic language, namely the language of the people) as they were created during the educational reform of 1929-1930; a reform inspired by the faith of those involved in the Ministry of Education to the movement of educational demoticism, under the leadership of the Minister of Education Georgios Papandreou ${ }^{3}$. The movement of Educational Demoticism took place between the years 1897-1922, and at the epicentre of this movement were the efforts made by the educationalists and linguistics for the introduction of demotic language into schools (Terzis, 1993). His ideas, already made clear in his article published in the Bulletin of Educational Association (Deltio tou Ekpaideytikou Omilou), which was the ideological instrument of demoticism, under the title The Boundaries of Demoticism ${ }^{4}$ (Ta oria tou dimotikismou), are put into practice with the curricula of this reform. In this article, G. Papandreou attempts - and to a large extent manages - to come up with a theoretical definition of demoticism. To be more specific, he associates demoticism with the sociopolitical situation as he makes a direct connection to four "social ideologies" or "sociological systems," according to his own definitions: (a) conservatism, (b) neo-liberalism, (c) liberalism/progressivism and (d) socialism; he concludes that Demoticism, though not a sociopolitical system, may be associated with either of the aforementioned systems (Papandreou, 1914).

The textbook literary anthologies of this period are the result of the curricula of the educational reforms mentioned above and they managed to change what the previous reforms had failed to change. Thus, for the first time, the teaching hours dedicated to the classical Greek language and classical Latin language were limited, while it is obvious that the teaching of the demotic language and Modern Greek literature was prioritized according to both quantity as well as

\footnotetext{
${ }^{3}$ The first incumbency of Georgios Papandreou as Minister of Education lasted from January 1930 until May 1932, during which he put into practice the principles of Demoticism regarding the use of demotic language in education and the diminishing of teaching of the classical Greek language and classical Latin language (Terzis, 1993).

${ }^{4}$ It is understood that Georgios Papandreou's first incumbency was not his first expression of preference to Demoticism.
} 
quality. Especially, concerning the amelioration of the teaching of Modern Greek Literature, it may be claimed that it is related to the introduction of the demotic language in middle schools but mainly to the minimum number of Modern Greek literature texts which were in 'katharevousa's taught (Terzis, 1993).

Within this background of reform and originality the introduction of a rather peculiar, at the time, poet was considered a welcome idea within the fields of educational policy. Although C. P. Cavafy was not entirely a demoticist - namely user of the demotic Greek language - since his poetic style was a mixture of demotic Greek with intentional archaic inclinations and the use of idioms of the Constantinople Greek, the language he used, being mainly demotic, would guarantee the originality and the immediateness, which were considered basic advantages of the demotic language (Kokoris, 2006; Politis, 2004).

But what were the different processes that took place in the field of literary criticism regarding the evaluation of C. P. Cavafy during the period 1900-1930? The first insightful opinion on the poetry of C. P. Cavafy was given by Gregorios Xenopoulos at the beginning of the $20^{\text {th }}$ century. In his text published in 1903, Xenopoulos attempted an evaluation of thirteen poems by Cavafy, out of which eight are fully embodied in his text and which he tried to assess in terms of form and content. Three out of

Within this background of reform and originality the introduction of a rather peculiar, at the time, poetry was considered a welcome idea within the fields of educational policy the aforementioned five poems with which Cavafy entered the school textbooks mentioned above were given a positive evaluation by Xenopoulos: 'Supplication', 'Candles' and most of all 'Thermopylae', which was the core in Xenopoulos' criticism and for which no other evaluation attempt had been made during the period 1900 1930 (Xenopoulos, 2003). In nearly every critique until 1930, which were not few but in most cases positive, the poem 'Thermopylae' was not mentioned at all or was dealt with in shorts (Agras, 1922; Thrylos, 1925; (Vrisimitzakis, 1923; Forster, 2003; Petridis, 2003; Segkopoulos, 2003). This allows us to consider Xenopoulos' critique as the clearest as well as the most up-todate and decisive one regarding the poem's inclusion in the journal Modern Art (Nea Techni), in 1924 (Souliotis, 1995), but mainly for its incorporation in the textbooks of 1930.

How were the rest of the poems included in the textbooks perceived by the audience? Let us resume from where we stopped; the textbook of grade 5 of secondary education is focusing

\footnotetext{
5"Katharevousa" was a form of Modern Greek language, an artificial Greek language based on Classical Greek, which is legally displaced in 1976 by Demotic Greek.
} 
specifically on the poem 'Trojans'. The background of this poem is historical-at least prima facieand was published in 1905 in the 'Panathinaia' journal; it was among the less anthologized poems by Cavafy for the period between 1900 and 1930, and the most important critique on it was that by Pavlos Petridis in 1909. His special article in the journal Modern Art (Nea Techni) in 19246, was the first journal to have ever included a poem by Cavafy. The 'Trojans' were anthologized by theme by Petridis in his text under the title "Constantinos P. Cavafy: An Alexandrian poet", in which he attempted a sociological and philosophical reading of the symbols of the poem. In the school literary anthology of secondary education grade 6, 'Candles' and 'Waiting for the Barbarians' were already under consideration. 'Candles', as mentioned, had been analyzed by Xenopoulos and a few years later by Petridis, while the critic Alkis Thrylos also attempted an analysis, though only partially, in his 1924 text "C.P. Cavafy".

'Candles' was anthologized by Xenopoulos, as previously mentioned, whereas the critic Alkis Thrylos also commented partially on the poem in his monograph entitled 'C.P. Cavafy' presented in 1924 (Thrylos, 1925; Xenopoulos, 2003; Petridis, 2003). 'Waiting for the Barbarians' was initially anthologized by Petridis in 1909, but was analyzed in depth by the critic Tellos Agras in his "The poet C. P. Cavafy" monograph, which was proven decisive for including Cavafy in the textbooks. His critique, presented as part of a lecture in 1921, was a systematic attempt to legalize Cavafy in education provided that: (a) it clearly set the boundaries of the duality of form and ideology as far as the creation of the poetic object is concerned, while at the same However, the lack of a specific and scientific outline from the history of literature point of view is obvious in education, and as a result the poems by Cavafy were sometimes included in the lyric section of the textbooks, while in other cases they were considered symbolic and dealt with as such time establishing this diptych as a mechanism of reading criteria configuration, (b) it researched the effect of Cavafy's poetic prose as an analogy of the symbolism of Mallarmé and Verlaine, the decadence of Baudelaire and perhaps Knut Hamsung's neo-Romanticism, (c) it established Cavafy's particularity in terms of style by placing this poetic style in the same category as that of the Greek poet Andreas Kalvos ${ }^{7}$ and (d) by being published in the Bulletin of Educational Association (Deltio tou Ekpaideytikou Omilou), his critique would

\footnotetext{
${ }^{6}$ In the special feature of the Nea Techni (Modern Art) journal on Cavafy there are 28 poems. The poems were not selected by the total of Cavafy's poems, as his work was in progress, but from the 115 poems written so far. The special feature on Cavafy has been

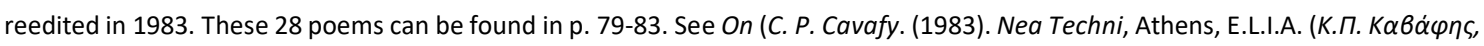

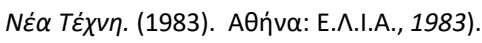

${ }^{7}$ Andreas Kalvos (1792-1869) was a Greek poet of the Romantic School and contemporary of the poet Dionysios Solomos. He also belongs to the 'Heptanese School of literature', in which Dionysios Solomos played a pivotal role.
} 
ensure his opinions would be noticed, a move that gave him the advantage of being indirectly associated to education, while at the same time putting him in a position to create the appropriate conditions that would help include Cavafy in education (Agras, 1922).

At times during which sophisticated verses and long poetics was the mainstream approach and the patriotic poetic style of the poet Kostis Palamas ${ }^{8}$ was the literary trend, the literary critique of 1900-1930 was the one that ensured Cavafy's inclusion in education in the early 1930s. However, the lack of a specific and scientific outline from the history of literature point of view is obvious in education, and as a result the poems by Cavafy were sometimes included in the lyric section of the textbooks, while in other cases they were considered symbolic and dealt with as such. The positive opinions by the critics and the momentum of anthologies that tried a holistic approach to poetry defined the inclusion of Cavafy in the school anthologies. Nevertheless, Cavafy's poems did not last for more than eight years, after which they were excluded without being replaced.

\section{From stagnation and censorship to establishment (1950 -1975)}

In 1938 C.P. Cavafy is excluded from school textbooks. The same year, the dictatorship of $4^{\text {th }}$ August 1936 by Ioannis Metaxas attempted to rewrite the textbooks based on the 1935 curricula, demonstrating a conservative turn regarding the teaching of literature contrary to the curricula and the anthologies of former years. The authorship of the new books was the result of the aforementioned negative change in politics, while the regime established by the dictatorship of $4^{\text {th }}$ August 1936 by Ioannis Metaxas and the foundation of O.E.A.B9 gave the modern spirit of the 1930's its "coup de grace" (Kountoura, 2006; Togias, 1988).

The textbook anthologies would more or less demonstrate the ideology of Metaxas' dictatorship and would keep the subject of literature dependent upon that of history. The aforementioned textbooks of Modern Greek Readings remained in education until 1950, as the Nazi Occupation of Greece (1941-1944) along with the Greek Civil War (1946-1949) that followed clearly impacted decisions in education. In these new anthologies, commissioned by the 4th August

\footnotetext{
${ }^{8}$ Kostis Palamas (1959-1943) was a Greek poet, a central figure of the Greek literary generation of the 1880s and the leader of the so-called 'New Athenian School'. He also wrote the lyrics of the 'Olympic Hymn'.

${ }^{9}$ To be exact, the Association for Editing of School Books (O.E.A.B) was founded in 1937 and the first books were written in 1938.
} 
regime, the conservative mentality of which had already been determined three years earlier, C. P. Cavafy was nowhere to be found (Kountoura, 2006).

Meanwhile, the Epitome of Modern Greek Literature by Elias Voutierides, which was published in 1933, did not include C. P. Cavafy. Voutierides proved incapable of understanding the modern spirit of Cavafy's poems and he criticized the form and the meaning of the poems based on ideological criteria and accused the poet of lack of normality in language use, lack of verse inspiration, vagueness and insignificant philosophical ideas and false aesthetics. At a time when the tug-of-war between demotic language and archaic 'katharevousa' was at its peak, Voutierides' arguments on Cavafy's uncharacterized and uncategorized language acted a useful weapon in the arsenal of the conservative enemies of Cavafy. Similarly strong was the argument on lack of verse creation, since the verses of Kostis Palamas were not only admirable, but also unquestionable. Finally, Voutierides confessed without hesitation his prejudice against Cavafy's homoeroticism, attributing a sanctimonious character to poetry. The low-profile poetry of C. P. Cavafy and the exploration of the human pathos in times of decadence did not match the patriotic style and the national pride of the curriculum and the dictatorship of $4^{\text {th }}$ August (Kountoura, 2006; Voutierides and Giakos, 1976).

The reunification of Cavafy's poetry with the history of Greek education took place twelve years later, in 1949, when the end of the Greek Civil War demanded the reconsideration of educational matters. In 1948, and before the end of the war, a call for writing new school textbooks is announced (Kountoura, 2006; Togias, 1988). From an ideological point of view, the textbook anthologies of that time did not differ from those of the dictatorship of the $4^{\text {th }}$ August period. Literature remained attached to history and served still the demands of the national ideals, resulting in the constructions of the national identity of young Greeks (Kountoura, 2006; Togias,

The low-profile poetry of C. P. Cavafy and the exploration of the human pathos in times of decadence did not match the patriotic style and the national pride of the curriculum and the dictatorship of 4th August 1988). In spite of the conservative nature of the school books of the time, published under the Association for Editing of School Books in 1950, C.P. Cavafy made a comeback with the poems 'Thermopylae' and 'Ithaka' in the sixth grade of secondary education ${ }^{10}$ (Kontopoulos and Papakostantinou, 1950) and in schools of professional education with the poems 'Ithaka', 'Candles' and 'The City' (Varelas, 2007).

${ }^{10}$ Nowadays High school Grade 3. 
The textbook anthologies of 1956 were written under the regime of the constitutionalized Greek-Christian turn in education (Charalampous, 1990) and it was only for the first time that the school literary canon differed so much from the literary canon. Although the History of Modern Greek Literature by C. Th. Dimaras, already published by 1948 , solved many problems regarding authors and their works, the book was not properly utilised in education. (Kountoura, 2006). It must be mentioned here that Dimaras spoke quite highly of Cavafy (Dimaras, 2000). C.P. Cavafy's presence in the school textbooks was modest, since only 'Thermopylae' in grade 5 of secondary education and 'Ithaka' and 'Thermopylae' in grade 6 of secondary education were to be found (Kalamatianos, Stathopoulou-Christofelli, Kontopoulos, Fotiades and Miniatis 1956 $\alpha$; Kalamatianos, Lagios and Stathopoulou - Christofelli, 1956ß). In addition, 'Ithaka' was under censorship therefore jeopardizing its teaching. The reason for this censorship was mainly due to the use of the word 'sensual' in the verse "sensual perfumes of every kind/as many sensual perfumes as you can." The poem was taught censored for nearly twenty years until its full restoration in 1982. In 1965, the two aforementioned poems would be studied for the Modern Greek Literature Diploma Assessment Examination, whereas 'Ithaka' together with Supplication would become part of the curriculum of naval education. (Varelas, 2007).

The edition of 154 poems by C. P. Cavafy in 1963 under G. P. Savidis played a pivotal part in the aesthetic establishment of the entire work of C. P. Cavafy. Linos Politis also played a part in the restoration of Cavafy, as far as the school textbook anthologies are concerned. He achieved this with his short 'History of Modern Greek Literature: short diagram - Bibliography' published in 1968, which offered in a few lines, yet clearly, a positive critique on Cavafy focusing on two axes: (a) the originality of Cavafy's poetry in terms of form and ideology and (b) the harmonious blend of meaning and form. Indeed, Politis specifically referred to Cavafy's modernism and focused on the inability of many critics of the time to comprehend his ideas and to express a positive opinion. (Politis, 1968).

In 1965, the seventh volume of Linos Politis' first edition of poetic anthology was released under the title Sikelianos - Cavafy and the newcomers, in which Politis included twenty-eight poems by Cavafy (Politis, 1965). Three out of the four of Cavafy's new entries were derived from Politis' anthology: 'The first step', included in the thematic section 'Social Life' for secondary education grade 4 (Vranousis, Sfiroeras, Kalamatianos, Romaios and Parris, 1975), 'Voices' and 'Alexandrian Kings' in secondary education grade 5 textbook (Kalamatianos, StathopoulouChristofelli, Kontopoulos, Fotiades and Miniatis, 1975a) and 'God abandons Antony' in the thematic section 'Lyrical Poems' along with 'Ithaka' and 'Thermopylae' in secondary education grade 6 (Kalamatianos, Lagios and Stathopoulou-Christofelli, 1975b). Thus, for the first time, the 
school literary canon was enriched with new poems in addition to historical ones, while one of them was included in the Social Life thematic section. In the meantime, new thinking is brought about regarding the effect of the history of literature in the school literary canon; it was the beginning of the regime of the History of Literature by C. Th. Dimaras and of the History of Literature by Linos Politis.

\section{From 'periphery' to the 'centre' (1977-2010): Cavafy's domination}

The necessity for education to be modernized, and more specifically the subject of literature, seems to take place approximately three years after the Restoration of Democracy. This modernization was indicated both by the new school textbooks for literature as well as the way their content was structured (Kountoura, 2006). The main features of the new textbook literary anthologies were: (a) the revised texts and (b) the utilization of the books regarding Modern Greek Literature which were written by C. Th. Dimaras and Linos Politis. As far as C. P. Cavafy is concerned, it is essential that we begin with the fact that Cavafy was taught for the first time in forty-seven years in the middle school; in grade 2 and 3 we find 'Poseidonians', 'In 200 B. C.', 'The first step', 'Those fought for the Achaean League' and 'June, 27, 1906, 2 p.m'. Let us indicate that the school literary canon was enriched as far as Cavafy is concerned, as not only were three poems to be included for the first time, but also two of these ('Poseidonians' and '27 June, 1906, 2 p.m') were not even among the 154 of the canon (Gregoriadis, Karvelis, Balaskas and Paganos, 1977; Gregoriadis, Karvelis, Balaskas and Paganos, 1979).

C. P. Cavafy seemed to be taking a dominant role in the new school textbook literary anthologies for high-school (grades 1 to 3 ) edited in the 80s; four of his poems were included in the school book literary anthology for high-school grade 2, whereas three more poems of Cavafy were found in the book for grade 3. All of the said poems were transferred to the school book of grade 1 in 2001. The school literary canon was enriched even more, as, apart from the restoration of 'Ithaka', after 30 years of censorship, the rest of the poems were new entries (Gregoriadis, Karvelis, Milionis, Balaskas, Paganos and Papakostas, 1982; Gregoriadis, Karvelis, Milionis, Balaskas, Paganos and Papakostas, 1983; Gregoriadis, Karvelis, Milionis, Balaskas, Paganos and Papakostas, 2001). 
The radical establishment of Cavafy seemed unstoppable, and during 1998-2008, poems by C.

The school literary canon was enriched even more, as, apart from the restoration of 'Ithaka', after 30 years of censorship, the rest of the poems were new entries
P. Cavafy were a sine qua non condition for all textbook anthologies. In 1998 the textbook of 'Modern European Literature' for high-school grade 2 included 'The Windows' and 'Che fece il gran rifiuto', while one year later iterature was introduced as a subject in the Arts and Humanities section, and Cavafy's poems which are selected were 'Caesarion', 'Dareius' and 'Melancholy of Jason Cleander,

poet in Commagini, A. D. 595'. In the school books of professional education, C. P. Cavafy was represented with 'Ithaka' and 'As much as you can'. In primary education (grades 5 and 6), edited in 2001, Cavafy poem 'Supplication' was included in the thematic section 'Our family'. The inclusion of Cavafy in primary education was a landmark, indeed. Another significant aspect was that the poem was no longer bound to the austere religious ideology but was now part of the more general and closer to the young age (Vagenas, 1998, Kagialis, Polkas, Tararas and Fragkoglou; Akrivos, Armaos, Karageorgiou, Bella and Belichoudi, 1999a; Angelakos, Deli, Konstantinidis and Baliami-Stefanakou, 2001a; Givalou- Katsiki, Kalogirou, Papadatos, Protonatoriou and Pylarinos, 2001).

For middle-school grades 1 and 2 textbook anthologies, edited in 2006 and based on the old curricula, we find Cavafy with 'Supplication', 'In Church' and 'Thermopylae' respectively. For grade 3, three poems by C. P. Cavafy are found: 'As much as you can', 'Voices' and the historical 'In the Year 200 B.C'. Some of Cavafy's poems were taught along with other poems and short stories, or parts of novels of other authors in all grades of middle and high school. (Pylarinos, Chatzidimitriou and Varelas, 2006a, 2006b; Garantoudis, Chatzidimitriou, and Menti, 2006a, 2006b; Kagialis, Dounia and Menti, 2006a, 2006b; Georgiadou, Katsiampoura, Kroupi - Kolona, Patouna, Chatzidimitriou - Paraschou and Chatzitheocharous, 2008a, 2008b, 2008c; Akrivos, Armaos, Karageorgiou, Bella and Belichoudi, 1999b).

However, what defined Cavafy's comeback in education during the 50's since the ideology of the educational curriculum remained conservative? One might say that it was Constantinos Th. Dimaras and his 'History of Modern Greek Literature' published in 1948. Let us examine its contribution to the establishment of C. P. Cavafy in the history of Greek literature. Dimaras examines Cavafy in the chapter entitled "Under the heavy shadow of Palamas" and specifically, in the subchapter "New falls - New hopes." Although Dimaras included C. P. Cavafy in the same subchapter with K. G. Karyotakis - for whom he expresses a negative opinion as he considers 
Karyotakis to represent the dissolution of traditional values - the poet from Alexandria, according to Dimaras, though special, does not represent fall, but hope (Dimaras, 2000).

Dimaras focuses on the influences upon C. P. Cavafy:

\begin{abstract}
Naturally, apart from the influences from the out-of-date Athenian Neo-Romanticism, Cavafy also had at his disposal other sources, clearer and more melodious, from where he could harvest poetic themes. The French Parnacism is on its peak, cold-blooded, noble, subtly, an exquisite antidote to the exaggerations of Romanticism (...). This second effect is soon to find its match: Symbolism, lacking half its tones, a state of submission, a state of relaxation, day-dreaming and abstractness closes the circle in which the new (sic) Cavafy is testing his powers (...) let us relate the philosophical poetry to Romanticism, the historical poetry to Parnacism and Aesthetics to Symbolism (...). His (Cavafy's) meter is the iambic, the finest match to out prose; his peculiar language, a mixture of archaic and demotic, is of course, due to a number of reasons (...).It is not enough to be simple, (...) it ought also be this: language must hide the world of emotions, not reveal it (...). This charm of the language, its coldbloodedness, is what allows us to feel that it rules the passion in an artistic manner (...). He has conquered the art of visions, the erotic visions, but without making it any easier for us to comprehend the historical visions (...). In addition, his out-of-theordinary eroticism, sometimes obvious in his poems, could also be a parting of inspiration: Has got something to hide under fake confessions that necessarily come with an element of arrogance ${ }^{11}$ (Dimaras, 2000, p. 597).
\end{abstract}

The presentation of Cavafy by Dimaras was scientific: (a) he placed Cavafy in the history of Modern Greek literature; (b) he associated Cavafy's life with his work; (c) he mentioned both the positive and the negative critiques of Cavafy up until then; (d) he assessed Cavafy's work based on chronological and style-related criteria; (e) he traced and theoretically organized the effects of Romanticism, Parnacism and Symbolism on Cavafy (Dimaras, 2000).

In 1977, Linos Politis published the revised edition of his poetic anthology changing the title from 'Sikelianos, Cavafy and the newcomers' to 'Cavafy, Sikelianos and poetry until 1930'. The title informs the reader of the significant position Cavafy now held in this volume. The aesthetic establishment offered by Politis can be understood if combined with his revised edition of his 1978 History of Modern Greek Literature as well as with the years his books were taught in the Department of Greek Medieval and Modern Greek Philology in the Aristotle University of Thessaloniki in Greece. In his chapter on C. P. Cavafy, Politis does not hesitate to place him in

${ }^{11}$ The translation is mine. 
The presentation of Cavafy by Dimaras was scientific: (a) he placed Cavafy in the history of Modern Greek literature; (b) he associated Cavafy's life with his work; (c) he mentioned both the positive and the negative critiques of Cavafy up until then; (d) he assessed Cavafy's work based on chronological and stylerelated criteria; (e) he traced and theoretically organized the effects of Romanticism, Parnacism and Symbolism on Cavafy the center of Modern Greek literature, pointing out that “(...) in the periphery of Hellenism, in Alexandria, a poet creates what was meant to be in the epicenter of the evolution of Modern Greek poetry"12 (Politis, 1977; Politis, 2004 , p. 227).

Linos Politis' History of Modern Greek Literature played a decisive role in the writing of the ninth series of school textbook anthologies, but at the same time another anthology was equally decisive and in favor of Cavafy. It was the volume Greek Poetry Anthology Grammatology published by Sokolis Editions. Cavafy's central place in this volume was not at all coincidental, as Costas Stergiopoulos' introduction on modernism deems C. P. Cavafy as its precursor. Should we attempt a comparison among the school anthologies from 1977 to 2001, it would not be hard to indicate that out of the thirteen of Cavafy's poems that were introduced in the school literary canon, eight were suggested by Linos Politis and Sokolis in their anthologies as well as in Politis' 'History of Modern Greek Literature' (Politis, 1977; Politis, 2004; Stergiopoulos, 1980).

\section{The beginning of an unquestionable restoration: New Curricula, 2011}

Although the course of Cavafy in the history of literature and in education seemed many times incompatible, given the reluctance to unconditionally embrace his work, the new curricula (Apostolidou, Kountoura, Prokopiou and Hontolidou, 2011) for literature and the efforts by the Ministry of Education to found the new school not only attempted to enlarge the school literary canon, but also managed to combine two canons: that of literature and that of education. The combining of the two allows us to certify not only the progress on a The fact that they are erotic poems is very important, because until then they were considered somehow a taboo for secondary education, mainly because of the poets' homosexuality scientific level, for which history of literature operates as an indicator, but also to conclude that this development was social as much as it was educational. Firstly, the examination of Cavafy outside the boundaries of the 'New Athenian School' and his

12 The translation is mine. 
inclusion in a larger group, that of the introducer of Modernism, restored his position in the school literary canon. In addition, the poems recommended for parallel reading in high school grade 1 under the thematic section 'Tradition and modernism of contemporary poetry', with the exception of the already anthologized 'Polis', were the following: 'Walls', 'Morning sea', 'Body, Remember...' and 'So much I gazed'; they were for the first time recommended for parallel reading contributing to the extension of the school literary canon. The fact that they are erotic poems is very important, because until then they were considered somehow a taboo for secondary education, mainly because of the poets' homosexuality. This was a form of restoration for C. P. Cavafy in education, but also a social breakthrough towards educational purposes, the significance of which may be attributed to or comprehended: (a) in relation to the school presence of C. P. Cavafy from the first time his work was included in an anthology until 2011; (b) under the prism of the social impact and the connection between society and the education and (c) within an educational and pedagogical background encouraging the students of the digital age to meet the work of C. P. Cavafy in a holistic prospect.

\section{Conclusions}

During a course of eighty years, C. P. Cavafy is found in thirty-five anthologies, teachers' textbooks and curricula, whereas the parallel reading recommendations reach a staggering eighty-seven; Ithaka is the most anthologized poem - twelve times. At times when sophisticated verses and long poetics was the mainstream approach and the patriotic poetic style of Kostis Palamas was the literary trend, literary critique of 1900-1930 ensured Cavafy's inclusion in education in early $30^{\prime}$ s. The positive opinions by the critics and the momentum of school anthologies that used a holistic approach to poetry defined the inclusion of C. P. Cavafy in the school anthologies during the educational reform of 1929-1932.

The position of Cavafy in the History of Modern Greek Literature by C. Th. Dimaras surpasses the efforts made by the critics of that time. It is a secure and unquestionable position which is now examined by a historian critic of literature, who traces, sets the boundaries and acknowledges the association of Cavafy to the literary trends. However, the knowledge offered by $C$. Th. Dimaras was not be included in school textbook anthologies until after the Restoration of Democracy (and mostly since 1977). Moreover, Linos Politis also partly responsible for the restoration of C. P. Cavafy as far as the school textbooks are concerned, as his History of Modern Greek Literature, as well as his poetic anthology, determined the school literary canon from the days of the Restoration of Democracy until now. The complete and unquestionable recognition 
of C. P. Cavafy as far as education is concerned, took place in 2011 through the efforts made by the designers of the NCS regarding literature. By introducing poems of Cavafy with a homosexual theme, the NCS designers managed to combine two canons, that of literature and that of education.

\section{References}

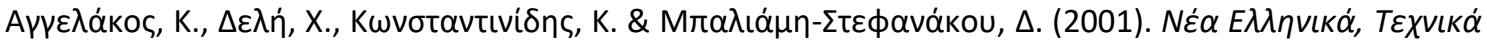

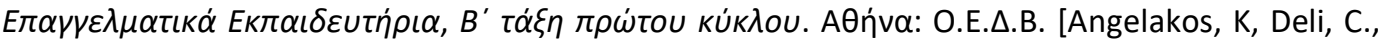
Konstantinidis, K., \& Baliami - Stefanakou, D. (2001). Modern Greeks, Technical and Professional Education, Grade 2 (First circle). Athens: O.E.D.B.].

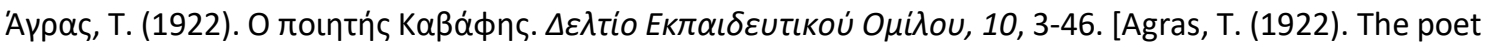
Cavafy. Bulletin of Educational Association (Deltio tou Ekpaideytikou Omilou) 10, 3-46].

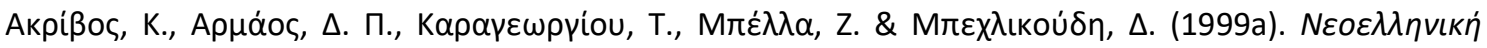

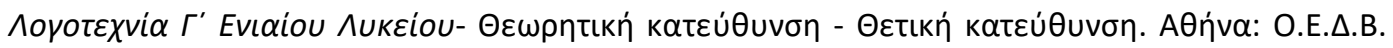
[Akrivos, K., Armaos, D.P., Karageorgiou, T., Bella, Z. \& Belichoudi, D. (1999a). Greek Modern Literature Grade 3 of High School - Theoretical direction - Science direction. Athens: O.E.D.B.].

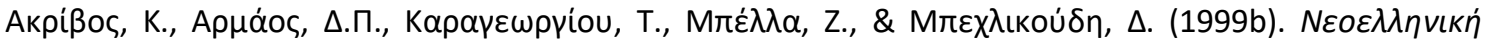

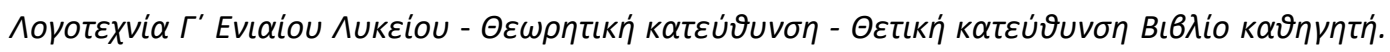
AӨńva: O.E.A.B. [Akrivos, K., Armaos, D.P., Karageorgiou, T., Bella, Z., \& Belichoudi, D. (1999b). Greek Modern Literature for Grade 3 of High School - Theoretical direction - Science direction. Teacher's book. Athens: O.E.D.B.].

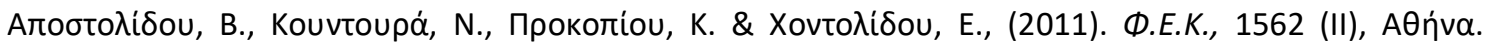
[Apostolidou, V., Kountoura, N., Prokopiou, K. \& Hontolidou, E., (2011). F.E.K, 1562 (II), Athens].

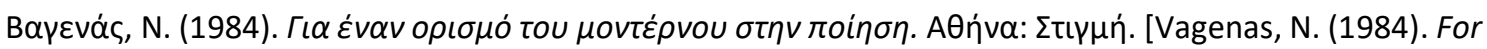
a definition of the modern in poetry. Athens: Stigmi].

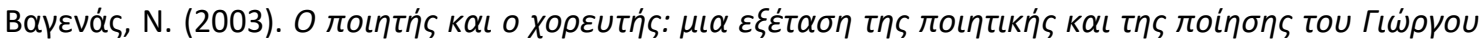

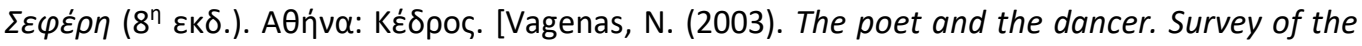
poetics and poetry of George Seferis' (8th ed.). Athens: Kedros].

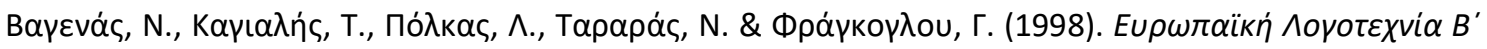

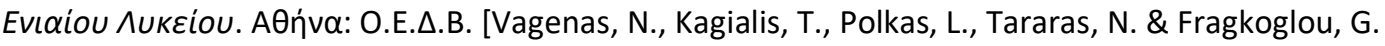
(1998). European Literature for Grade 2 of High - school. Athens: O.E.D.B.].

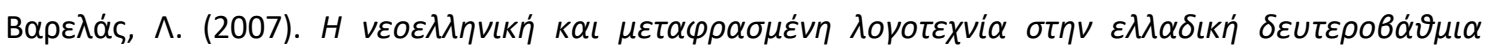

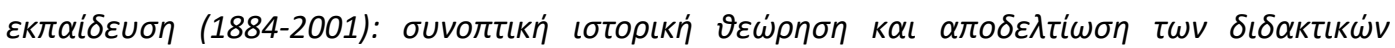
$\varepsilon \gamma \chi \varepsilon \iota \rho ı \delta i \omega v . ~ \Theta \varepsilon \sigma \sigma \alpha \lambda$ ovíkn: K.Е.Г. [Varelas, L. (2007). The Greek Modern and translated literature in Greek Secondary education (1884-2001): brief historical perspective and entry of the school books'. Thessaloniki: K.E.G.]. 


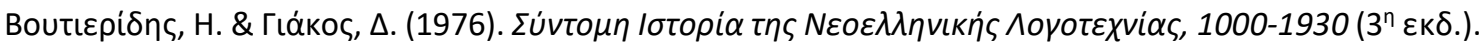

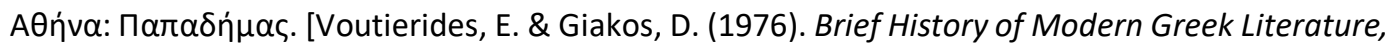
1000- 1930 (3rd ed.). Athens: Papadimas.]

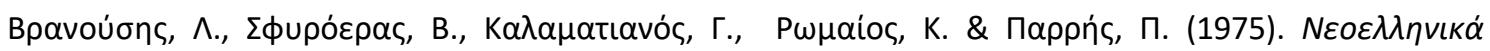

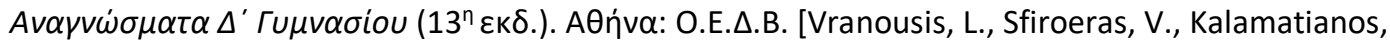
G., Romaios, K. \& Parris, P. (1975). Greek modern Readings of Grade 4 for secondary education (13th ed.). Athens: O.E.D.B.

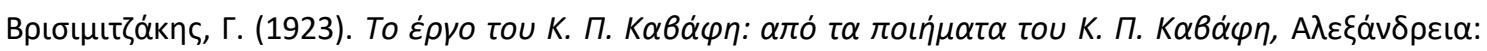

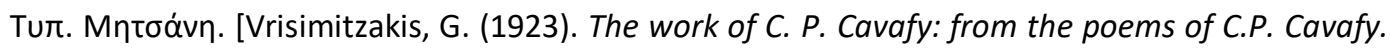
Alexandria: Mitsani].

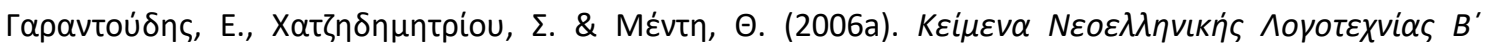

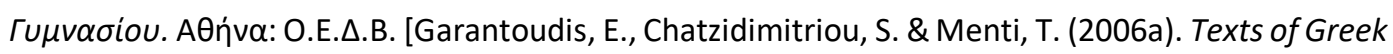
Modern Literature of Grade 2 for Middle School. Athens: O.E.D.B.].

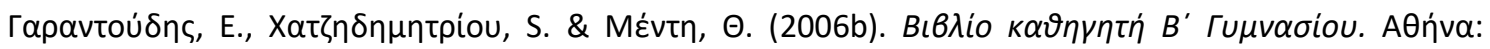
O.E.A.B. [Garantoudis, E., Chatzidimitriou, S. \& Menti, T. (2006b). Texts of Greek Modern Literature of Grade 2 for Middle School- Teacher's Book. Athens: O.E.D.B.].

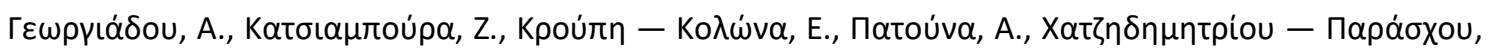

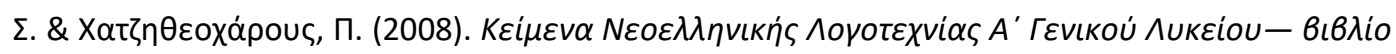

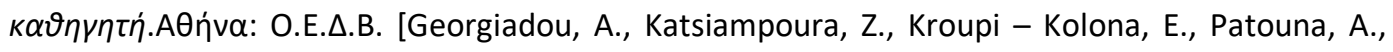
Chatzidimitriou - Paraschou, S. \& Xatzitheocharous, P. (2008). Texts of Greek Modern Literature of Grade 1 for High - School - Teacher's Book, Athens: O.E.D.B.].

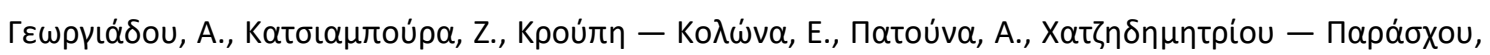

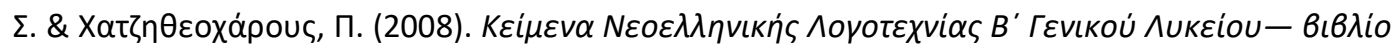

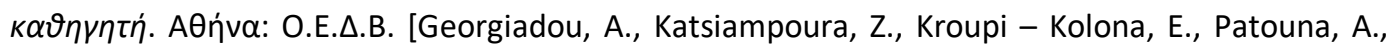
Chatzidimitriou - Paraschou, S. \& Xatzitheocharous, P. (2008). Texts of Greek Modern Literature of Grade 2 for High - School - Teacher's Book, Athens: O.E.D.B.].

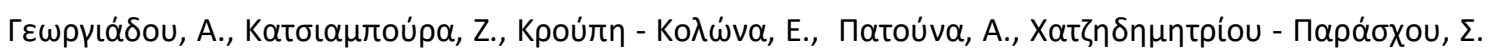

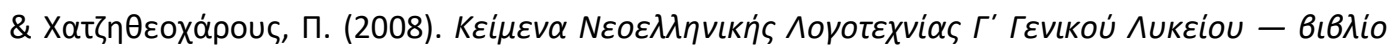

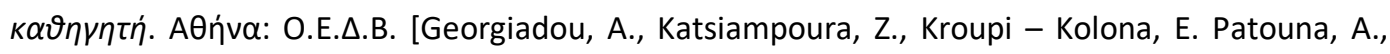
Chatzidimitriou - Paraschou, S., Xatzitheocharous, P. (2008). Texts of Greek Modern Literature of Grade 3 for High - School - Teacher's Book, Athens: O.E.D.B.].

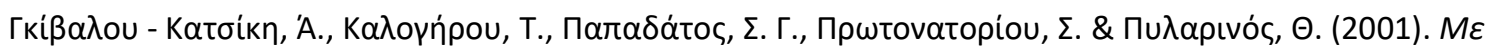

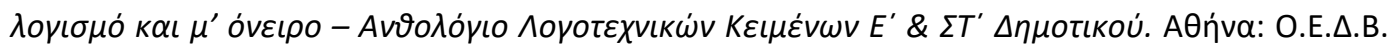
[Givalou - Katsiki, A., Kalogirou, T., Papadatos, G. S., Protonatoriou, S. \& Pylarinos, T. (2001). With Reflection and Dream - Anthology of Literary Tetxs' for Grades 5 \& 6 of Primary Education. Athens: O.E.D.B.]. 


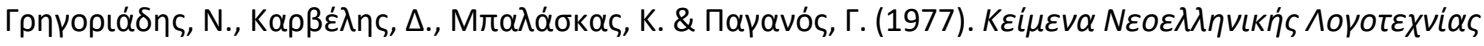

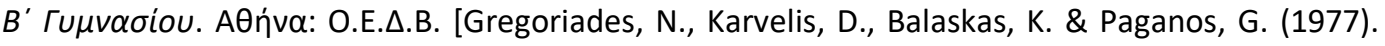
Texts of Greek Modern Literature of Grade 2 for Middle-School, Athens: O.E.D.B.].

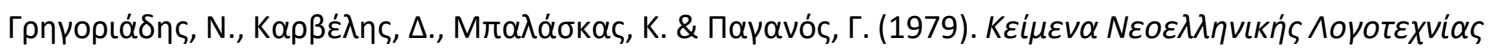

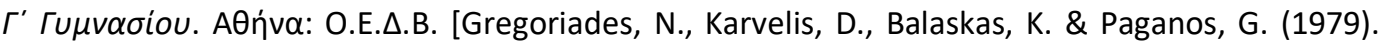
Texts of Greek Modern Literature of Grade 3 for Middle-School, Athens: O.E.D.B.].

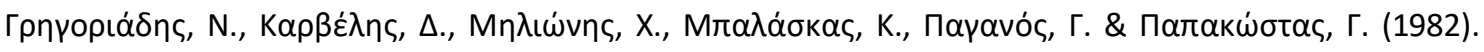

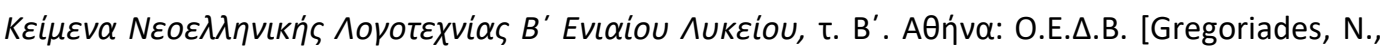
Karvelis, D., Milionis, Ch., Balaskas, K., Paganos, G. \& Papakostas, G. (1982). Texts of Greek Modern Literature of Grade 2 for High - School, Athens: O.E.D.B.].

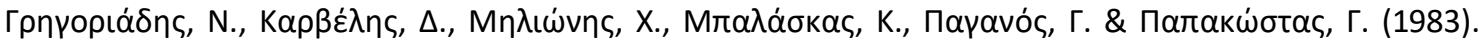

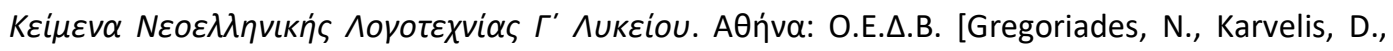
Milionis, Ch., Balaskas. K., Paganos, G. \& Papakostas, G. (1983). Texts of Greek Modern Literature of Grade 3 for High - School, Athens: O.E.D.B.].

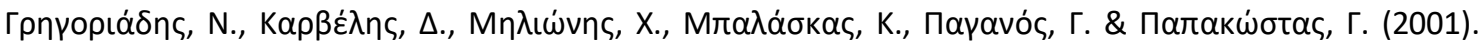

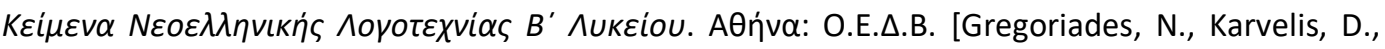
Milionis, Ch., Balaskas. K., Paganos, G. \& Papakostas, G. (2001). Texts of Greek Modern Literature of Grade 2 for High - School. Athens: O.E.D.B.].

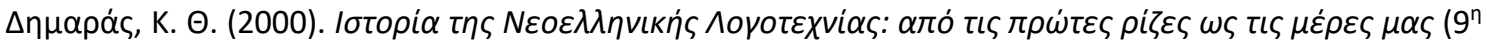

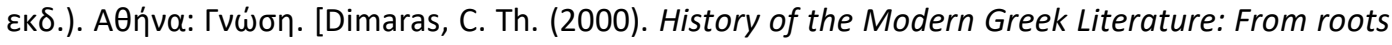
until nowadays (9th ed.). Athens: Gnosi].

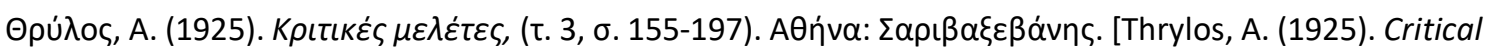
Studies, (Vol. 3, pp. 155-197). Athens: Sarivaxevanis].

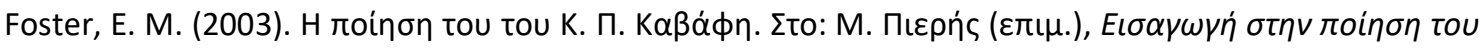

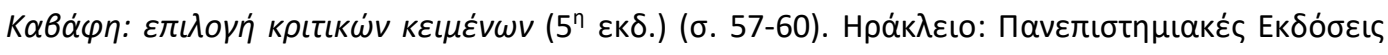
Kpńtns. [Foster, E.M. (2003). The poetry by C. P. Cavafy. In: M. Pieris (Ed.), Introduction to Cavafy's poetry: Selected critical texts (5th ed.) (pp. 57-60). Heraklion: University of Crete Press].

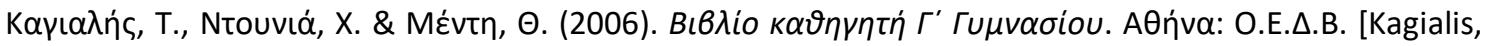
T., Dounia, C. \& Menti, T. (2006). Teacher's Book of Grade 3 of High-School. Athens: O.E.D.B.].

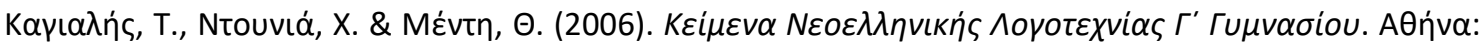
O.E.A.B. [Kagialis, T., Dounia, C. \& Menti, T. (2006). Texts of Greek Modern Literature of Grade 3 for Middle-School. Athens: O.E.D.B.].

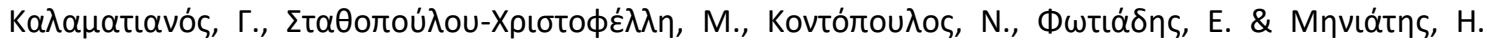

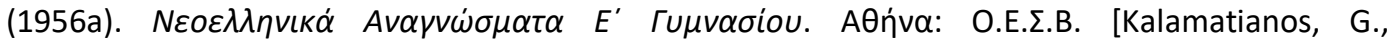
Stathopoulou - Christofelli, M., Kontopoulos, N., Fotiades, E. \& Miniatis, E. (1956a). Greek modern Readings of Grade 5 for secondary education. Athens: O.E.D.B.]. 


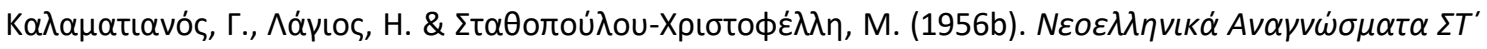

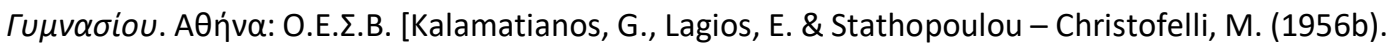
Greek modern Readings of Grade 6 for secondary education. Athens: O.E.D.B.].

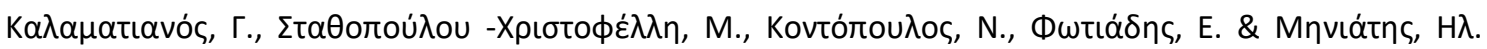

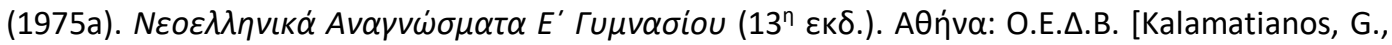
Stathopoulou - Christofelli, M., Kontopoulos, N., Fotiades, E. \& Miniatis, E. (1975a). Greek modern Readings of Grade 4 for secondary education (13th ed.). Athens: O.E.D.B.].

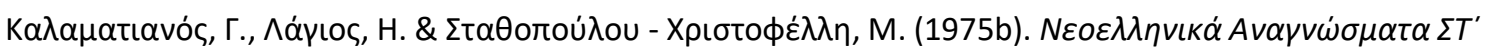

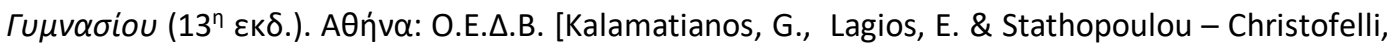
M. (1975b). Greek modern Readings of Grade 6 for secondary education (13th ed.). Athens: O.E.D.B.].

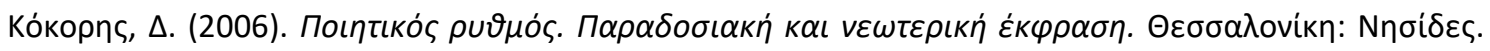
[Kokoris, D. (2006). Poetic Rhythm. Traditional and modern expression. Thessaloniki: Nisides.].

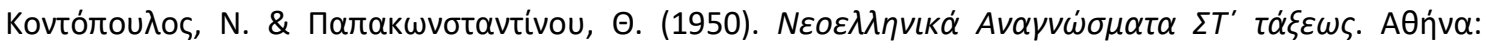
O.E.E.B. [Kontopoulos, N. \& Papakonstantinou, T. (1950). Greek modern Readings of Grade 6 for secondary education. Athens: O.E.S.B.].

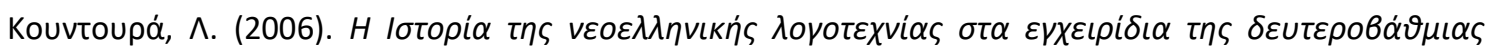

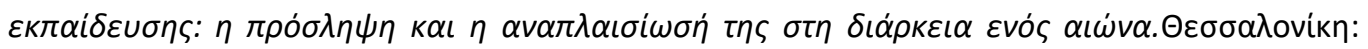
Kupıаkínৎ. [Kountoura, L. (2006). The History of Greek Modern Literature in textbooks of the secondary education: the reception and its recontextualisation over a century. Thessaloniki: Kyriakidis].

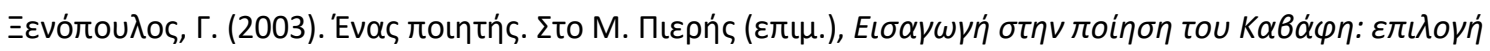

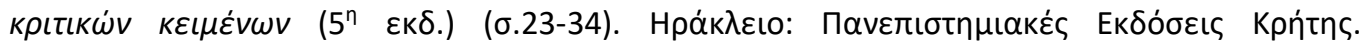
[Xenopoulos, G. (2003). A poet. In: M. Pieris (Ed.), Introduction to Cavafy's poetry: Selected critical texts (5th ed.) (pp. 23-34). Heraklion: University of Crete Press].

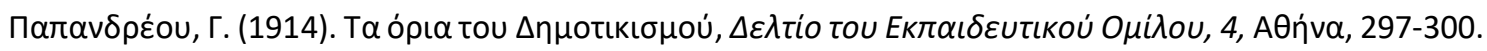
[Papandreou, G. (1914). The boundaries of Demoticism, Bulletin of Educational Association (Deltio tou Ekpaideytikou Omilou), 4, Athens, 297-300].

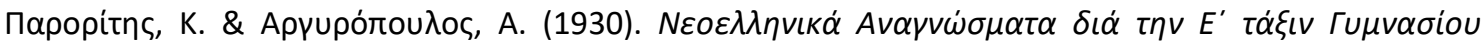

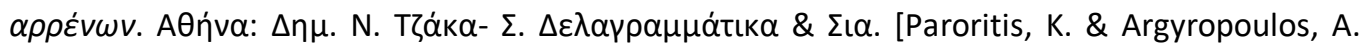
(1930). Greek modern Readings of Grade 5 for secondary education of males. Athens: Dim. N. Tzaka - S. Delagrammatika \& Co].

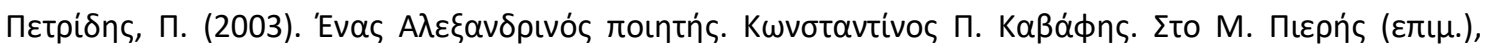

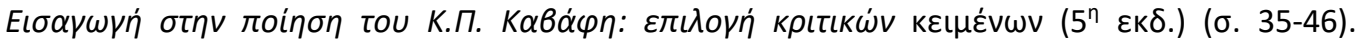

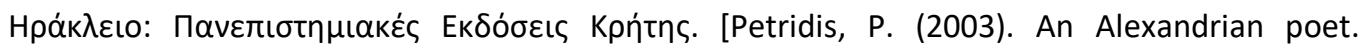
Constantinos P. Cavafy. In: M.Pieris (Ed.), Introduction to Cavafy's poetry: Selected critical texts (5th ed.) (pp. 35-46). Heraklion: University of Crete Press]. 


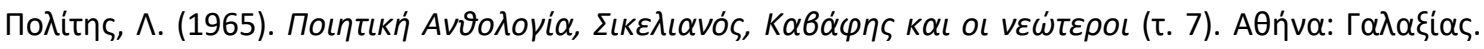
[Politis, L. (1965). Anthology of Poetry. Sikelianos, Cavafy and the newcomers (V. 7). Athens: Galaxias].

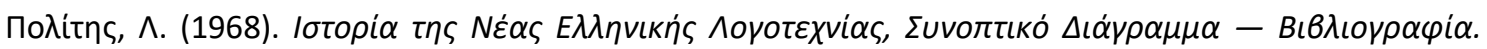

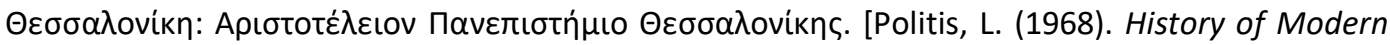
GreekLiterature, Short diagram - Bibliography. Thessaloniki: Aristotle University of Thessaloniki].

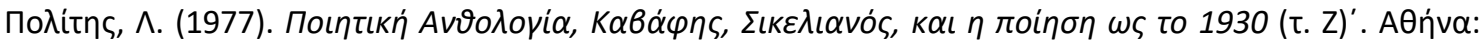
$\Delta \omega \delta \omega ́ v \eta$. [Politis, L. (1977). Anthology of Poetry. Cavafy, Sikelianos and poetry until 1930 (v. VII). Athens: Dodoni].

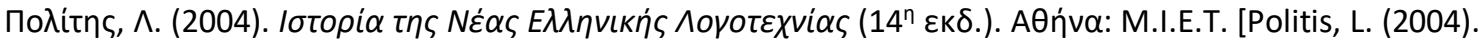
History of Modern Greek Literature (14th ed.). Athens: M.I.E.T.].

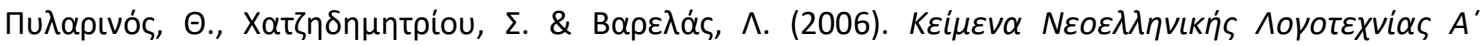
Гupvaoiou. AӨńva: O.E.A.B. [Pylarinos, T., Chatzidimitriou, S. \& Varelas, L. (2006). Texts of Greek Modern Literature of Grade 1 for Middle-School. Athens: O.E.D.B.].

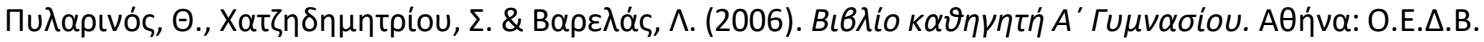
[Pylarinos, T., Chatzidimitriou, S. \& Varelas, L. (2006). Teacher's Book of the Grade 1 of Middle School. Athens: O.E.D.B.].

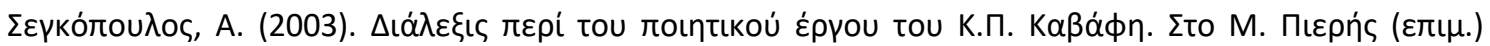

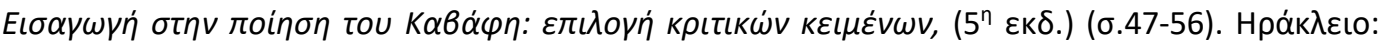

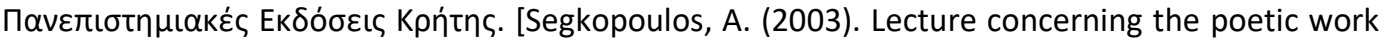
of C. P. Cavafy. In: M. Pieris (Ed.), Introduction to Cavafy's poetry: Selected critical texts (5th ed.) (pp. 47-56). Heraklion: University of Crete Press].

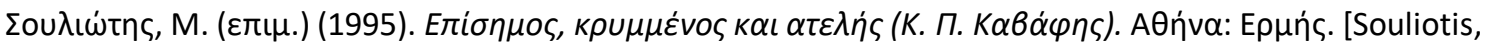
M. (Ed) (1995). Recognised, hidden and in complete (C. P. Cavafy). Athens: Hermes].

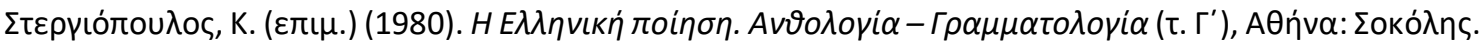
[Stergiopoulos, K. (Ed) (1980). The Greek Poetry. Anthology - Grammatology (Vol. III). Athens:.].

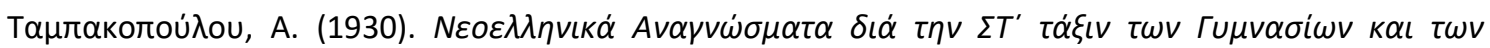

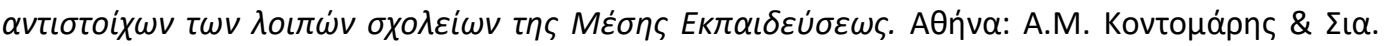
[Tampakopoulou, A. (1930). New Greeks Readings for Grade 6 of secondary Education. Athens: A. M. Kontomaris \& Co.].

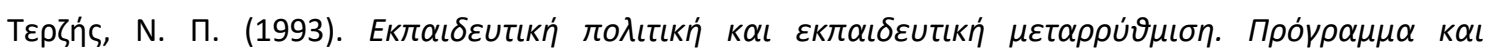

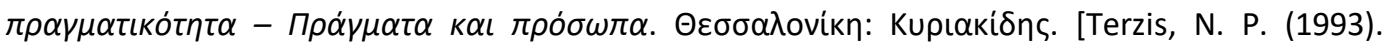
Educational Policy and Educational Reform. Program and Reality - Matters and Persons. Thessaloniki: Kyriakides].

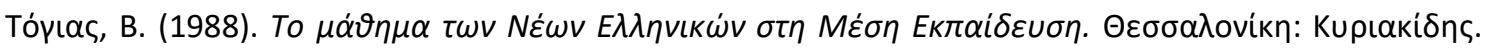
[Togias, V. (1998). The subject of the Modern Greek in Secondary Education. Thessaloniki: Kyriakides]. 


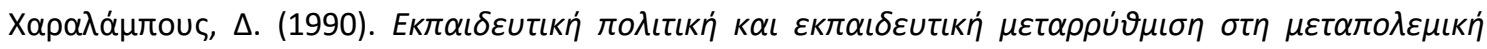

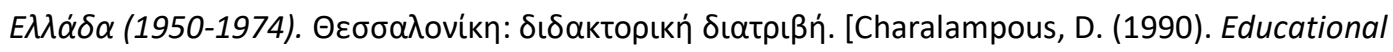
Policy and Educational Reform in Post - War Greece. Thessaloniki: doctoral thesis].

How to cite this paper:

Kalasaridou, S. (2019). The Presence of C. P. Cavafy in Greek Education: Landmarks and Gaps. Journal of Literary Education, (2), pp. 90-109. doi: 10.7203/JLE.2.12049 